\title{
Preliminary Appraisal of Imposex in Areas Under the Influence of Southern Brazilian Harbors
}

\author{
I. B. de Castro, ${ }^{1,2}$ C. E. Bemvenuti ${ }^{2}$ \& G. Fillmann ${ }^{2 *}$ \\ ${ }^{1}$ Laboratório de Zoobentos, Instituto de Ciências do Mar, LABOMAR/UFC, Av. da Abolição, 3207, \\ Bairro Meireles, CEP 60165-081, Fortaleza, CE, Brasil \\ ${ }^{2}$ Fundação Universidade Federal do Rio Grande, C.P. 474, CEP 96201-900, Rio Grande, RS, Brasil \\ (Received November 1, 2006; Accepted January 10, 2007)
}

\begin{abstract}
Imposex in gastropod mollusks is an efficient and low-cost biomarker for pollution by organotin compounds. Such substances are typically found in areas with an intense flux of vessels, such as marinas and harbors. This study preliminarily evaluated the occurrence of imposex in Stramonita haemastoma (Linnaeus, 1758) populations along the areas under the influence of the main harbors from southern Brazil (Paranaguá, PR; São Francisco do Sul, SC; Itajaí, SC; and Rio Grande, RS). Although no chemical analyses were performed so far to confirm the presence of organotins, the occurrence of imposex strongly suggests a contamination by these compounds in the studied areas and it is likely that the closest from the harbors (as the main sources) the more contaminated the environment. However, due to the limitations of S. haemastoma, it is important to assess the response of alternative species adapted to mesohaline environments and non-consolidated substrates, in order to make up for the lack of indicator species for some areas such as Patos Lagoon and Itajaí-Açu estuaries.
\end{abstract}

Key words: imposex, Stramonita haemastoma, organotin, estuary, southern Brazil.

\section{RESUMO}

\section{Avaliação preliminar de imposex em área sob a influência de portos do sul do Brasil}

O imposex em moluscos gastrópodes é um eficiente biomarcador de baixo custo para contaminação por compostos orgânicos de estanho. Esses compostos são tipicamente encontrados em áreas com intenso fluxo de embarcações, como marinas e terminais portuários. O presente estudo verificou preliminarmente a ocorrência de imposex em populações de Stramonita haemastoma (Linnaeus, 1758) ao longo das áreas sob a influência dos principais terminais portuários do sul do Brasil (Paranaguá, PR, São Francisco do Sul, SC, Itajaí, SC, e Rio Grande, RS). Apesar de não confirmados quimicamente, a ocorrência de imposex em todas as áreas estudadas sugere contaminação por compostos orgânicos de estanho, sendo possivelmente tanto maior quanto mais próxima dos portos (ou das fontes). Porém, em razão das limitações de $S$. haemastoma, é importante avaliar essa resposta em espécies alternativas que suportem ambientes mesohalinos e com substratos não consolidados, possibilitando assim avaliação mais completa de ambientes como os estuários da Lagoa dos Patos e Itajaí-Açu.

Palavras-chave: imposex, Stramonita haemastoma, organoestanho, estuário, sul do Brasil.

*Corresponding author: Gilberto Fillmann, e-mail: gilberto@ pesquisador.cnpq.br. 


\section{INTRODUCTION}

Imposex is the appearance of male sexual features (penis and vas deferens) in neogastropod females exposed to organotin compounds (tributyltin and triphenyltin) (Gibbs \& Bryan, 1987). This is a highly specific biomarker, which indicates physiological changes associated with the reproductive organs in gastropods exposed to organotin compounds (Matthiessen \& Gibbs, 1998). Such compounds are found mainly in antifouling paints used for the coating of ships and aquaculture structures (Horiguchi et al., 1994). Therefore, it has been widely used worldwide to monitor the contamination of aquatic environments (Morcillo \& Porte, 1998; Axiak et al., 2003; Minchin, 2003), being reported in 132 species of gastropod mollusks (Castro et al., in press).

Some cases of imposex were reported in Latin America, specifically in Chile using Nucella crassilabrum, Chorus giganteus, Xantochorus cassidiformes (Gooding et al., 1999) and Acanthina monodon (Osorio \& Huaquin, 2003), and in Argentina using Bucinanops monilifer, Adelomelon brasiliana (Penchaszadeh et al., 2001) and Olivancillaria auricularia (Cledon et al., 2006) as bioindicators. Imposex was also found at Northeast and Southeast coast of Brazil during monitoring studies using the muricid Stramonita haemastoma at Ceará (Castro et al., 2000), Paraíba, Pernambuco (Castro, 2005) and Rio de Janeiro (Fernandez et al., 2002; Fernandez et al., 2005), and Stramonita rustica at Rio Grande do Norte (Castro et al., 2004), Alagoas (Camillo et al., 2004) and Sergipe (Castro et al., 2005). Caetano \& Absalão (2003) also found imposex in the olivid Olivancillaria vesica at coastal areas of Rio de Janeiro. All of these studies showed a clear relationship with distance from harbors.

Considering the lack of previous studies, this work aims to preliminarily verify the occurrence of imposex in areas under the influence of the most important harbors of Southern Brazil (e.g. Paranaguá-PR, São Francisco do Sul-SC, Itajaí-SC and Rio Grande-RS) using Stramonita haemastoma as a bioindicator.

\section{MATERIALS AND METHODS}

Four harbors in the southern region of Brazil were chosen based on their cargo load and annual flow of vessels. Up to five sampling stations were chosen for the region under the influence of each harbor based on the distance from potential sources of contamination, availability of Stramonita haemastoma (Linnaeus, 1758) and local dynamics (Table 1).

Table 1 - Position (latitude and longitude) of the sampling stations and their distance from the main harbor.

\begin{tabular}{|c|c|c|c|c|c|c|}
\hline Harbor & Station & Description & Latitude & Longitude & $\begin{array}{c}\text { Distance from } \\
\text { harbor }(\mathbf{k m})\end{array}$ & $\begin{array}{c}\text { N. ships/ } \\
\text { year* }\end{array}$ \\
\hline \multirow{5}{*}{$\begin{array}{c}\text { Paranaguá } \\
\text { (Paranaguá } \\
\text { Bay) }\end{array}$} & E1 & Galheta Island & $26^{\circ} 55^{\prime} 11^{\prime \prime}$ & $48^{\circ} 38^{\prime} 28^{\prime \prime}$ & 23.93 & \multirow{5}{*}{2252} \\
\hline & E2 & Mel Island & $25^{\circ} 34^{\prime} 24^{\prime \prime}$ & $48^{\circ} 19^{\prime} 01^{\prime \prime}$ & 23.53 & \\
\hline & E3 & Marina & $25^{\circ} 32^{\prime} 41^{\prime \prime}$ & $48^{\circ} 22^{\prime} 31^{\prime \prime}$ & 17.00 & \\
\hline & E4 & Guará Island & $25^{\circ} 28^{\prime} 45^{\prime \prime}$ & $48^{\circ} 31^{\prime} 36^{\prime \prime}$ & 2.87 & \\
\hline & E5 & Gererê Island & $25^{\circ} 29^{\prime} 02^{\prime \prime}$ & $48^{\circ} 34^{\prime} 31^{\prime \prime}$ & 4.22 & \\
\hline \multirow{5}{*}{$\begin{array}{c}\text { São Francisco } \\
\text { do Sul } \\
\text { (Babitonga } \\
\text { Bay) }\end{array}$} & E1 & Paulas Beach & $26^{\circ} 13^{\prime} 39^{\prime \prime}$ & $48^{\circ} 36 ' 59^{\prime \prime}$ & 2.28 & \multirow{5}{*}{395} \\
\hline & E2 & Ingleses Beach & $26^{\circ} 13^{\prime} 45^{\prime \prime}$ & $48^{\circ} 37^{\prime} 39^{\prime \prime}$ & 1.32 & \\
\hline & E3 & Northeastern Harbor & $26^{\circ} 13^{\prime} 53^{\prime \prime}$ & $48^{\circ} 38^{\prime} 6,7^{\prime \prime}$ & 0.66 & \\
\hline & E4 & Tourist Harbor & $26^{\circ} 14^{\prime} 30^{\prime \prime}$ & $48^{\circ} 38^{\prime} 24^{\prime \prime}$ & 0.45 & \\
\hline & E5 & Flores Island & $28^{\circ} 15^{\prime} 54^{\prime \prime}$ & $48^{\circ} 42^{\prime} 31^{\prime \prime}$ & 6.19 & \\
\hline \multirow{4}{*}{$\begin{array}{c}\text { Itajaí } \\
\text { (Itajaí-Açu } \\
\text { estuary) }\end{array}$} & E1 & Brava Beach & $26^{\circ} 55^{\prime} 43^{\prime \prime}$ & $48^{\circ} 37^{\prime} 39^{\prime \prime}$ & 5.37 & \multirow{4}{*}{902} \\
\hline & E2 & Cabeçudas Beach & $26^{\circ} 55^{\prime} 17^{\prime \prime}$ & $48^{\circ} 38^{\prime} 12^{\prime \prime}$ & 3.52 & \\
\hline & E3 & Outside of South Jetty & $26^{\circ} 54^{\prime} 56^{\prime \prime}$ & $48^{\circ} 28^{\prime} 23^{\prime \prime}$ & 2.99 & \\
\hline & E4 & Outside of North Jetty & $26^{\circ} 54 ' 37^{\prime \prime}$ & $48^{\circ} 34^{\prime} 30^{\prime \prime}$ & 2.57 & \\
\hline \multirow{5}{*}{$\begin{array}{l}\text { Rio Grande } \\
\text { (Patos Lagoon } \\
\text { estuary) }\end{array}$} & E1 & Ship Wreck - 16 km South of E2 & $32^{\circ} 17^{\prime} 29^{\prime \prime}$ & $52^{\circ} 15^{\prime} 34^{\prime \prime}$ & 19.32 & \multirow{5}{*}{1652} \\
\hline & E2 & Outside base of West Jetty & $32^{\circ} 09^{\prime} 39^{\prime \prime}$ & $52^{\circ} 05^{\prime} 49^{\prime \prime}$ & 1.42 & \\
\hline & E3 & Outside end of West Jetty & $32^{\circ} 11^{\prime} 00^{\prime \prime}$ & $52^{\circ} 05^{\prime} 00^{\prime \prime}$ & 5.24 & \\
\hline & E4 & Outside end of East Jetty & $32^{\circ} 08^{\prime} 50^{\prime \prime}$ & $52^{\circ} 04^{\prime} 40^{\prime \prime}$ & 5.62 & \\
\hline & E5 & Outside base of East Jetty & $32^{\circ} 10^{\prime} 56^{\prime \prime}$ & $52^{\circ} 04^{\prime} 30^{\prime \prime}$ & 2.48 & \\
\hline
\end{tabular}

*Source: Ministério dos Transportes, 2006. 
Up to 30 adult specimens (20-30 $\mathrm{mm}$ ) of $S$. haemastoma were sampled (either manually or by free diving) in each station during January 2006. The organisms were stored in plastic bags, labeled and taken to the laboratory where they were narcotized with a $3.5 \% \mathrm{MgCl}$ solution for a period of 2 hours. Shells were then measured with a caliper $(0.05 \mathrm{~mm})$ from the spiral tip to the end of the siphon channel. Thus, shells were removed for the analysis of the soft tissues. Gender identification was based on the presence of a seminal receptacle (only in females) and the prostate gland (only in males).

The imposex levels were quantified using the following indexes: \% of imposex in females, Relative Penis Length Index (RPLI) and the Vas Deferens Development Stage Index (VDSI). The RPLI was calculated by mean penis length in females/ mean penis length in males) $\times 100$ (Gibbs \& Bryan, 1987), while the VDSI comprised the six-stage scale proposed by Gibbs \& Bryan (1994) for Nucella lapillus and modified by Fernandez et al. (2005) for organisms of Stramonita genus.

\section{RESULTS}

Paranaguá Bay (PR). Most of the stations sampled at Paranaguá Bay showed an imposex occurrence higher than $85 \%$, with the highest levels found in stations E4 (located in front of the Paranaguá harbor) and E3 (located nearby a big marina were many small boats were moored). Station E1 showed the lowest levels, since it was located in the outer part of the bay and far away from possible sources (Figure $1)$.

Babitonga Bay (SC). The levels found in the inner part of the Bay showed an imposex gradient decreasing with increasing distance from the São Francisco do Sul harbor. Stations E4 (south from the harbor) and E3, E2 and E1 (north from it) showed imposex in 100\% of the sampled organisms with an RPLI as high as 65.0. On the other hand, the organisms from station E5 did not show any sign of imposex, due to probably its upstream location (Figure 2).

Itajaí-Açu estuary and adjacent coastal area (SC). Two out of four sampled stations under the influence of the Itajaí Harbor showed imposex. Stations E3 and E4, both at the jetties of the harbor entrance, showed imposex in $100 \%$ of the sampled organisms with an RPLI of 3.8 and 1.8, respectively (Figure 3). Stations E2 and E1 did not show any sign of imposex, possibly because of their location at the adjacent coast and far away from the harbor.

Patos Lagoon estuary and adjacent coastal area (RS). Imposexed animals were found in every sampling station, with the highest indexes found at the west jetty protecting the west side of the access to the Rio Grande harbor (e.g. E2 and E3) (Figure 4). Even located far away from the harbor and southwards along the coast, station E1 showed imposex in 18\% of the sampled organisms (Figure 4).

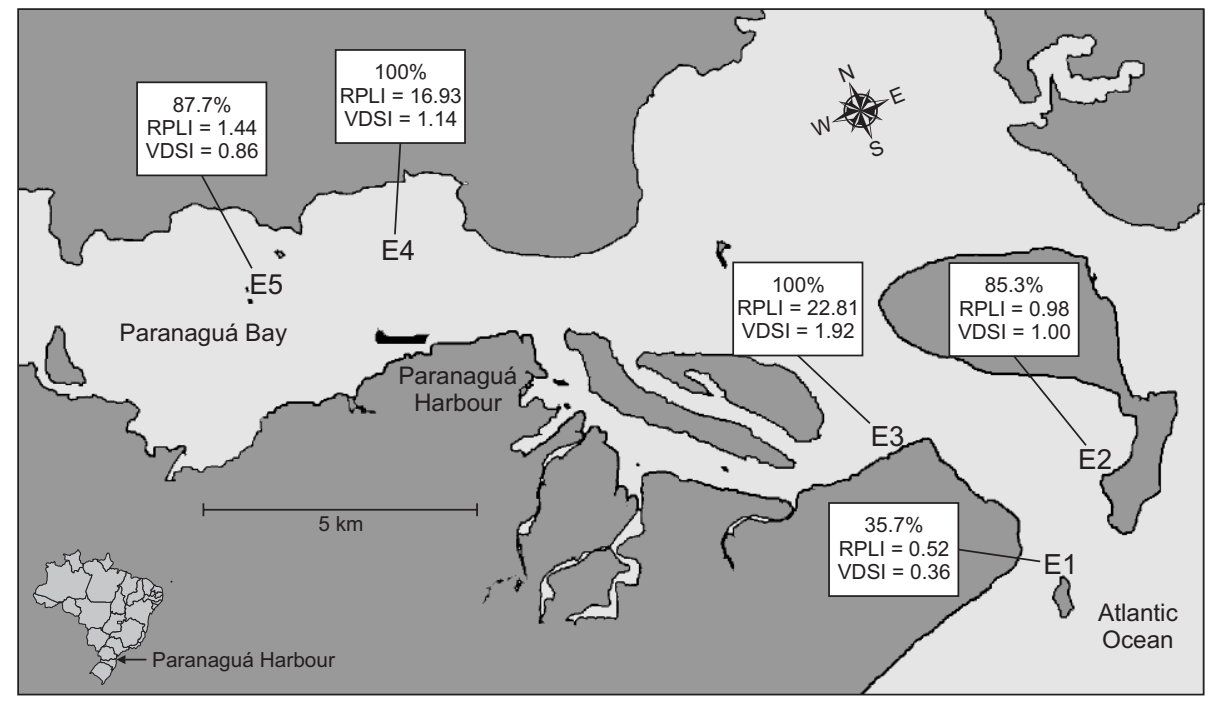

Figure 1 - Imposex frequency (\%), RPLI and VDSI for each station sampled at Paranaguá Bay (PR). 


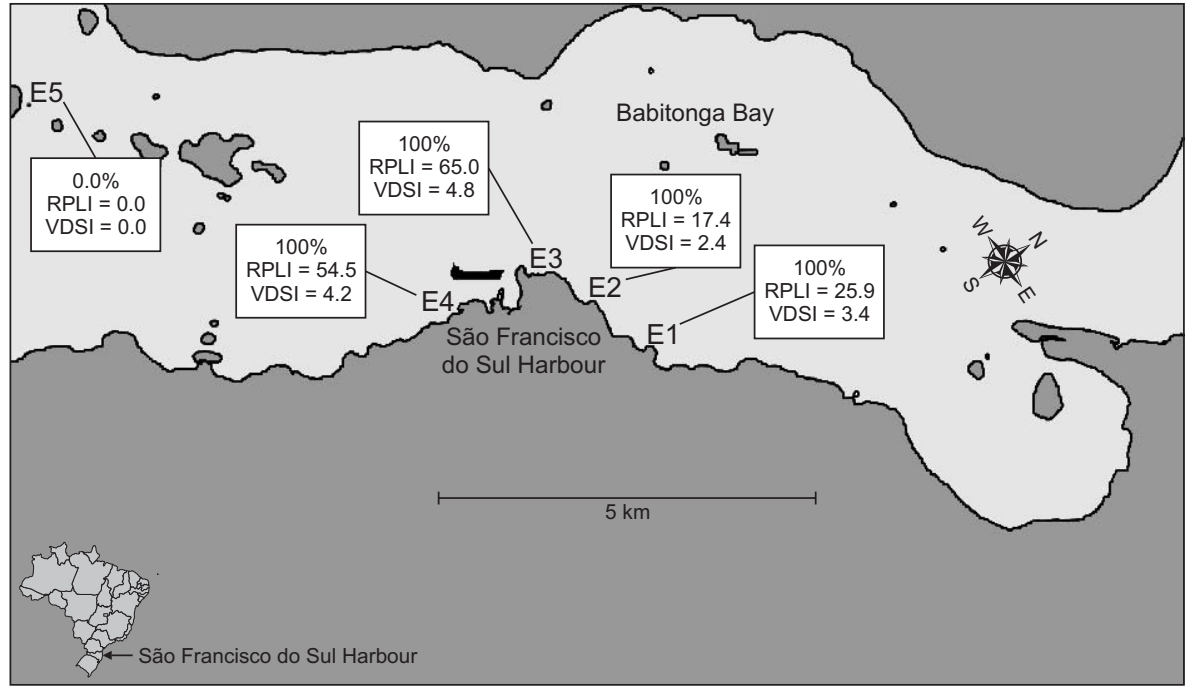

Figure 2 - Imposex frequency (\%), RPLI and VDSI for each station sampled at Babitonga Bay (SC).

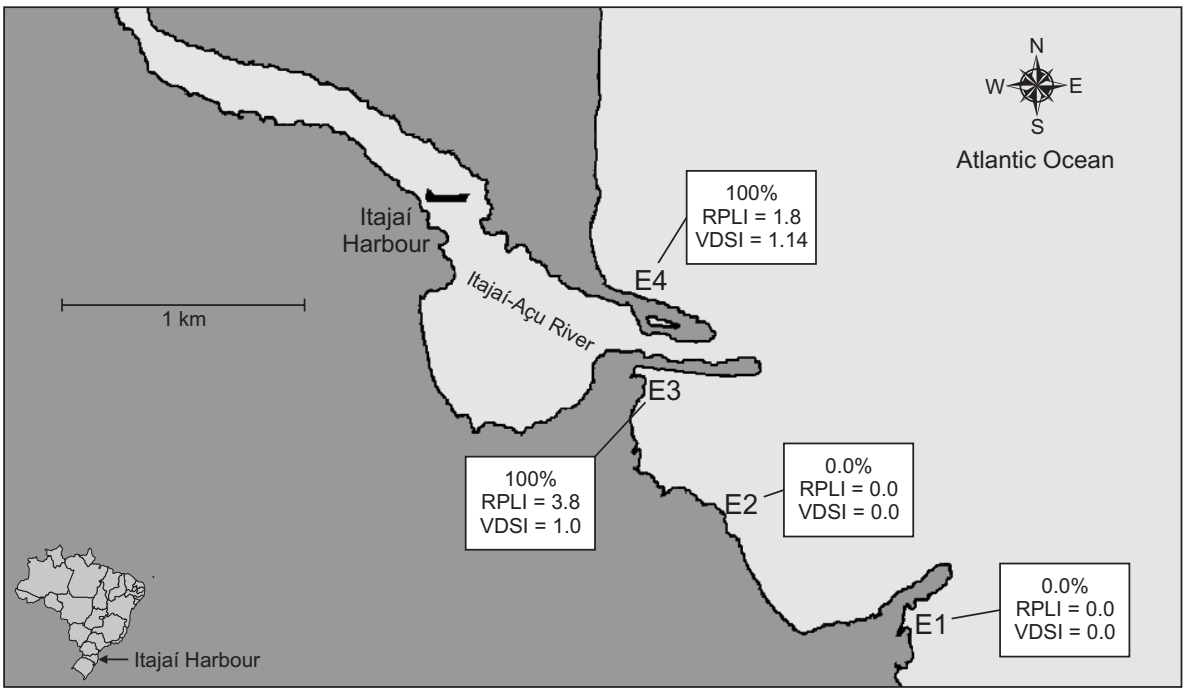

Figure 3 - Imposex frequency (\%), RPLI and VDSI for each station sampled nearby the Itajaí harbor and adjacent coastal area.

\section{DISCUSSION}

Stramonita haemastoma was chosen for this study because 38 out of 132 species reported as presenting imposex were from the Thaididae family, and 18 belonged to the genus Stramonita (Castro et al., in press). This fact makes this family and this genus as well, most commonly taxon used as a bioindicator of contamination by organotin compounds all over the world. Furthermore, Stramonita haemastoma presents a wide geographical distribution, being found in consolidated substrates in the intertidal zone practically all along the Brazilian coastline (Matthews, 1968). Additionally, no evidences of natural occurrence of imposex in muricid mollusks (such as Stramonita haemastoma) were found so far. 


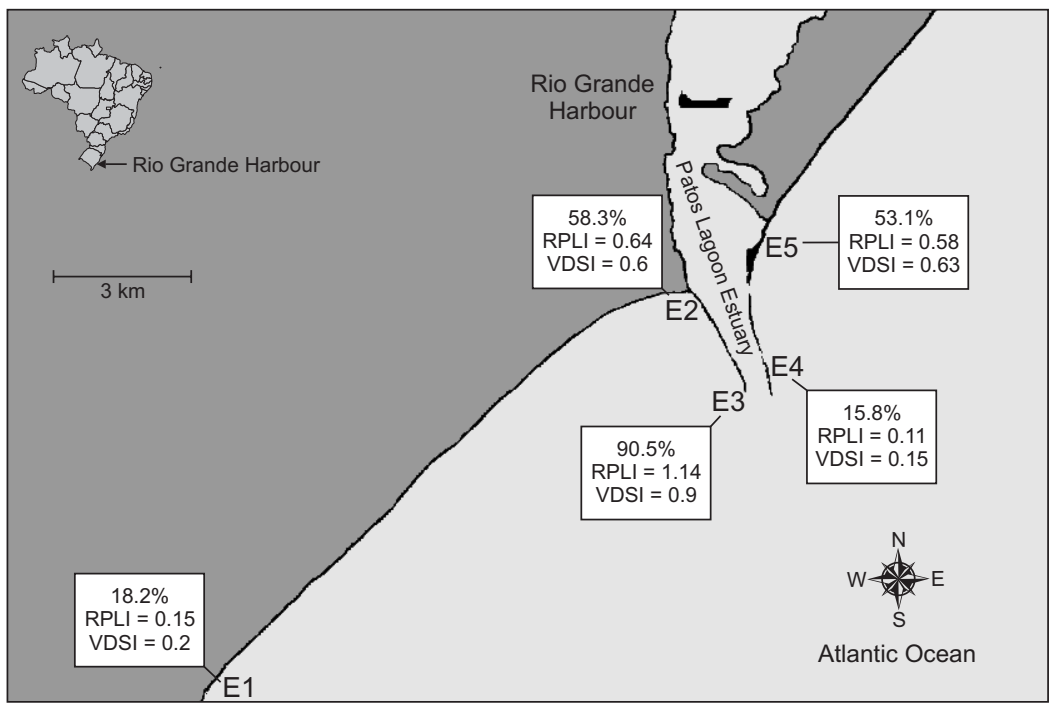

Figure 4 - Imposex frequency (\%), RPLI and VDSI for each station sampled nearby the Rio Grande harbor and adjacent coastal area.

Sixteen out of nineteen stations sampled at harbors of southern Brazil showed imposex in S. haemastoma. Even showing one of the lowest vessel movements (mean of 352 vessels/year; Table 1), the highest indexes of imposex were found in Babitonga Bay, on station under the influence of São Francisco do Sul harbor. That is probably due to a reduced water exchange rate, which increases the time of exposure to the contaminants. An imposex gradient was observed as a function of distance from the harbor. Similar patterns are often seen in monitoring surveys at open sea (Castro et al., 2000).

Conversely, the Patos Lagoon estuary showed the lowest imposex indexes, even under the influence of one of the biggest Brazilian harbors (Ministério dos Transportes, 2006). Although the local dynamics and dilution capacity of each region were not taken in consideration, the Patos Lagoon estuary has probably one of the highest water exchange rates (Garcia, 1997) among the studied systems. The difficulty to find $S$. haemastoma individuals in areas under the direct influence of Rio Grande harbor has also some influence since the system has a highest capacity to dilute any substance released into its waters. S. haemastoma was found only at the outer faces of the jetties, since the inner ones and the estuary itself very often presents very low salinity, which are not tolerated by this mollusk.

The highest imposex indexes of Paranaguá Bay were found at the station closer to the harbor (station E4) and to a marina (station E3), where an intense flow of recreational boats was observed. However, based on its highest movement of vessels (a mean of 2252 vessels/year; Table 1) and intense flux of recreational boats, Paranaguá Bay should have shown higher imposex levels, which could also be explained by a high capacity to dilute the contaminants. Although most studies on organotin contamination deal mainly with big harbors, it is important to consider the pollution caused by the marinas, where only small and medium-sized boats are found. Studies carried out in marinas of Phuket Island (Thailand) showed imposex levels as high as those found in big harbors around the globe (Bech, 2002).

The Itajaí harbor has a mean annual flow of 902 vessels, mostly constituted by recreational and fishing boats (Ministério dos Transportes, 2006). The results showed the influence of coastal currents on stations located southwards from the entrance of the estuary. Stations E1 and E2 shown no imposex, while stations located at the jetties (E3 and E4) showed the highest indexes of imposex due probably to the permeability of the jetty to the waters coming from the inner estuary. A similar pattern also occurs at the Natal harbor (Northern Brazil) (Castro et al., 2004). However, more detailed studies are needed to confirm this hypothesis.

The results indicated a pattern in the distribution of imposex, once indexes degreased with the distance from some of the monitored harbors (or possible sources). Similar results were observed in studies carried out in the Mediterranean with Hexaplex trunculus (Axiak et al.,1995), in the Sanriku region in Japan with Thais clavigera (Horiguchi et al., 1998), in Crok Harbour, Ireland, with Nucella lapillus and Littorina littorea (Minchin et al., 1996), in Phuket Island, Thailand, with Chicoreus capucinus and Thais distinguenda (Bech, 2002), 
in Killybegs, Ireland, with Nucella lapillus and Littorina littorea (Minchin et al., 1997), as well as in many harbors in the Brazilian northeast (Castro et al., 2004; Castro et al., 2005).

The use of OTCs is a matter of controversy in the international scientific community. In 1996, the United Nations Marine Environment Protection Committee (MEPC) suggested a gradual elimination of TBT-based paints during the following 10 years. This proposal was exhaustively discussed by several countries, and its prohibition was postponed to 2008 (ten Hallers-Tjabbes et al., 2003). Some countries (such as Japan, New Zealand and France) have already banned the use of these compounds in their territories. Other countries such as Canada, USA, South Africa, Australia and most of the European Union countries have limited the use of OTCs to vessels longer than 25 meters (Champ, 2000). In a general way, these prohibitions were motivated by the proved toxicity of OTCs to the biota (ten Hallers-Tjabbes, 1997).

On January $1^{\text {st }}, 2005$ came into effect a new Brazilian resolution for water quality standards (CONAMA 357, 2005). For the first time levels were established for tributyltin (TBT), with maximum allowed concentrations of 0.01 and $0.37 \mu \mathrm{g}$ $\mathrm{L}^{-1}$ for Class 1 and 2 salty waters, respectively. Although this regulation represents an improvement, ecotoxicological studies using native species are needed in order to establish more realistic limits, once impacts on marine populations have been reported for exposure to concentrations as low as $0.001 \mu \mathrm{g}$ $\mathrm{L}^{-1}$ (Alzieu, 2000), which are much lower than those set by the above-mentioned regulation.

The results obtained in the present study indicate that every single Southern Brazilian harbor is probably already contaminated by OTCs and possibly the closest from the harbors (as the main sources) the more contaminated the environment. Although no chemical analyses were performed so far to confirm the presence of organotins, the occurrence of imposex strongly suggests a contamination by these compounds in the studied areas (Matthiessen \& Gibbs, 1998). Thus, this screening data will help focusing more detailed future studies, where the unconditional confirmation of contamination will be achieved with the chemical analyses.

In some areas, such as Patos Lagoon estuary and ItajaíAçu River, imposex indexes were not as high as expected, due probably to the lack of Stramonita haemastoma populations in the low salinity regions close to those harbors. Other limitation is that S. haemastoma survives only on consolidated substrates such as jetties, rocky shores and harbor columns. Therefore, it is important to assess the response of alternative species, adapted to mesohaline environments and non-consolidated substrates, in order to make up for the lack of indicator species for those areas. In addition, the hydrodynamics must be considered to the better understanding of OTCs distribution along the environment.
Finally, in view of the fact that the continuous worldwide banishment of the organotin-based antifouling paints is likely to reduce their environmental relevance, the present study represents very important baseline information that can be used in the future to evaluate the effectiveness of the total ban.

Acknowledgements — The authors would like to thank the Center of Marine Studies of the Federal University of Paraná (CEM/UFPR), and especially the members of the Benthos Laboratory: Cynthia Simone Gomes dos Santos, Igor Pessoa and André Senna Garafoni. G. Fillmann was sponsored by CNPQ (PQ 303218/2003-7)

\section{REFERENCES}

ALZIEU, C., 2000, Environmental impact of TBT: the French experience. Sci Total Environ., 258: 99-102.

AXIAK, V., VELLA, A. J., MICALLEF, D., CHIRCOP, P. \& MINTOFF, B., 1995, Imposex in Hexaplex trunculus (Gastropoda: Muricidae): first results from biomonitoring of tributyltin contamination in the Mediterranean. Mar. Biol., 121: 685-691.

AXIAK, V., MICALLEF, D., MUSCA, T. J., VELLA, A. J. \& MINTOFF, B., 2003, Imposex as a biomonitoring tool for marine pollution by tributyltin: some further observations. Environ. Int., 28: 743-749.

BECH, M., 2002, Imposex and tributyltin contamination as a consequence of the establishment of a marina, and increasing yachting activities at Phuket Island, Thailand. Environ. Pollut., 117: 421-429.

CAETANO, C. H. S. \& ABSALÃO, R. S., 2003, Imposex in Olivancillaria vesica vesica (Gmelin) (Gastropoda, Olividae) from a Southeastern Brazilian sandy beach. Rev. Bras. Zool., 19: 215-218.

CAMIllo, E., QUADROS, J., CASTRO, I. B. \& FERNANDEZ, M. A. S. 2004, Imposex in Thais rustica (Mollusca: Neogastropoda) (Lamarck, 1822 ) as an indicator of organotin compounds pollution at Maceio coast (Northeastern Brazil). Braz. J. Ocean., 52: 101-105.

CASTRO, I. B., 2005, Estudo do imposex em muricídeos do gênero Stramonita (Mollusca: Gastropoda) no Nordeste do Brasil. Dissertação de Mestrado, Instituto de Ciências do Mar, Universidade Federal do Ceará, Fortaleza, CE, $187 \mathrm{p}$.

CASTRO, I. B., MATTHEWS-CASCON, H. \& FERNANDEZ, M. A. S., 2000, Imposex em Thais haemastoma (Linnaeus, 1767) (Mollusca: Gastropoda) uma indicação da contaminação por organoestânicos na costa do município de Fortaleza. Arq. Ciên. Mar, 33: 51-56.

CASTRO, I. B., MEIRELleS, C. A. O., MATTHEWS-CASCON, H. \& FERNANDEZ, M. A. S., 2004, Thais (Stramonita) rustica (Lamarck, 1822) (Mollusca: Gastropoda: Thaididae), a potential bioindicator of contamination by organotin in Northeast Brazil. Braz. J. Ocean., 52: 135-139.

CASTRO, I. B., CAVALCANTE-BRAGA, A. R. \& ROCHA-BARREIRA C. A., 2005, Altos índices de imposex em Stramonita rustica (Mollusca: Gastropoda) em áreas portuárias dos estados de Alagoas e Sergipe, Brasil. Trop. Ocean., 33: 121-128.

CASTRO, I. B., MEIRELLES, C. A. O., PINHEIRO, J. C. L., MATTHEWSCASCON, H. \& ROCHA-BARREIRA, C. A., 2005, The increasing incidence of imposex in Stramonita haemastoma (Mollusca: Gastropoda: Muricidae) after the establishment of the Pecem Harbor, Ceará state, Northeast Brazil. Thalassas, 21: 71-75.

CASTRO, I. B., RODRIGUES, L. \& ROCHA-BARREIRA, C. A., 2007, Compostos orgânicos de estanho: efeitos sobre a fauna marinha - uma revisão. Arq. Cien. Mar, in press. 
CHAMP, M. A., 2000, A review of organotin regulatory strategies, pending actions, related costs and benefits. Sci. Total Environ., 258: 21-71.

CLEDON, M., THEOBALD, N., GERWINSKY, W. \& PENCHASZADEH, P. E., 2006, Imposex and organotin compounds in marine gastropods and sediments from the Mar del Plata coast, Argentina. J. Mar. Biol. Ass. U.K., 86: 1-5.

CONAMA 357, 2005, National Council of Environment (CONAMA). Resolution $\mathrm{N}^{\mathrm{o}} 357$, March $17^{\text {th }}$, 2005. Ministry of Environment (MMA). Government of Brazil, 23 p.

FERNANDEZ, M. A. S., LIMAVERDE, A. C., CASTRO, I. B., WAGENER, A. L. R. \& ALMEIDA, A. C. O., 2002, Occurrence of imposex in Thais haemastoma: possible evidence of environmental contamination derived from organotin compounds in Rio de Janeiro and Fortaleza, Brazil. Rep. Public Health, 18: 463-476.

FERNANDEZ, M. A. S., WAGENER A. L. R., LIMAVERDE, A. C., SCOFIELD, A. L., PINHEIRO, F. M. \& RODRIGUES, E., 2005, Imposex and surface sediment speciation: A combined approach to evaluate organotin contamination in Guanabara Bay, Rio de Janeiro, Brazil. Mar. Environ. Res., 59: 435-452.

GARCIA, C. A. E., 1997, Hydrographic characteristics, pp. 18-20. In: U. Seeliger, C. Odebrecht \& J. Castello (eds.), Subtropical convergence marine ecosystem: the coast and the sea in the warm temperate southwestern Atlantic. Springer-Verlag, Berlin, Germany.

GIBBS, P. E. \& BRYAN, G. M., 1987, TBT paints and demise of the dogwhelk Nucella lapillus (Gastropoda). J. Mar. Biol. Assoc. U.K., 68: 14821487.

GIBBS, P. E. \& BRYAN, G. M., 1994, Biomonitoring of tributyltin (TBT) pollution using the imposex response of neogastropod mollusks. In: J. M. Kramer Kees (ed.), Biomonitoring of coastal waters and estuaries. Boca Ratón, EUA, CRC Press Inc., p. 2005-226.

GOODING, M., GALLARDO, C. \& LEBALANC, G., 1999, Imposex in three marine gastropod species in Chile and potential impact on muriciculture. Mar. Poll. Bull., 38: 1227-1231.

HORIGUCHI, T., SHIRAISHI, H., SHIRAISHI, H. \& MORITA, M., 1994, Imposex and organotin compounds in Thais clavigera and T. bronni in Japan. J. Mar. Biol. Assoc. U. K., 74: 651-669.

HORIGUCHI, T., HYEON-SEO, C., SHIRAISHI, H., SHIBATA, Y., SOMA, M., MORITA, M. \& SHIMIZU, M., 1998, Field studies on imposex and organotin accumulation in the rock shell, Thais clavigera, from the Seto Insland Sea and the Sanriku region, Japan. Sci. Total Environ., 214: 6570.
MATTHEWS, H. R., 1968, Notas sobre o gênero Thais (Roding, 1798) no Nordeste brasileiro. Arq. Est. Biol. Mar, 8: 37-41.

MATTHIESSEN, P. \& GIBBS, P. E., 1998, Critical appraisal of the evidence for tributyltin - mediated endocrine disruption in mollusks. Environ. Toxicol. Chem., 17: 37-43.

MINCHIN, D., STROBEN, E., OEHLMANN, J., BAUER, B., DUGGAN, C. B. \& KEATINGE, M., 1996, Biological indicators used to map organotin contamination in Cork Harbour, Ireland. Mar. Pollut. Bull., 32: 188195.

MINCHIN, D., BAUER, B., OEHLMANN, J., SCHULTE-OEHLMANN, U. \& DUGGAN, C. B., 1997, Biological indicators used to map organotin contamination from a fishing port, Killybegs, Ireland. Mar. Pollut. Bull., 34: $235-243$.

MINCHIN, D., 2003, Monitoring of tributyltin contamination in six marine inlets using biological indicators. Mar. Environ. Health., 6: 1-15.

MINISTÉRIO DOS TRANSPORTES. Available in: http://www.transportes. gov.br/. Accessed in: October $6^{\text {th }} 2006$.

MORCILLO, Y. \& PORTE, C., 1998, Monitoring of organotin compounds and their effects in marine mollusks. TRAC, 17: 109-116.

OSORIO, C. \& HUAQUIN, L. G., 2003, Alteración de la sexualidad de Acanthina monodon (Pallas, 1774) (Gastropoda: Muricidae) en el litoral de Chile central, inducida por compuestos organoestañosos. Cienc. Tecnol. Mar., 26: 97-107.

PENCHASZADEH, P. E., AVERBUJ, A. \& CLEDÓN, M., 2001, Imposex in gastropods from Argentina (southwestern Atlantic) Nucella lapillus and the common whelk Buccinum undatum as indicators of TBT contamination. Mar. Pollut. Bull., 42: 790-791.

TEN HALLERS-TJABBES, C. C., 1997, Tributyltin and policies for antifouling. Environ. Technol., 18: 1265-1268.

TEN HALLERS-TJABBES, C. C., WAGERNER, J., HATTUM, B. V., KEMP, J. F., TEM HALLERS, E., REITSEMA, T. J. \& BOON, J. P., 2003, Imposex and organotin concentrations in Buccinum undatum and Neptunea antiqua from the North Sea: relationship to shipping density and hydrological conditions. Mar. Environ. Res., 55: 203-233. 